\title{
Linguocultural Analysis of Nominations of Fingers in the Selkup Language ${ }^{1}$
}

\author{
Anastasia Persidskaya \\ Lecturer, National research Tomsk Polytechnic University, Tomsk, Russia \\ Email: Persidskaya@tpu.ru \\ Natalia Polyakova \\ Associate Professor, Tomsk State Pedagogical University, Tomsk, Russia \\ Email:nvp@tspu.edu.ru
}

\section{Doi:10.5901/mjss.2015.v6n3s2p448}

\begin{abstract}
The article presents linguocultural analysis of nominations of fingers in the Selkup language. The aim of the study is to reveal the part of the Selkup worldview comprised in the lexical units under study. The authors systematize the variants of nominations of fingers as well as identify linguistic and cultural principles for nomination while studying the etymology of nomination of a finger in general and carrying out the component and comparative analyses of the nominations of particular fingers of a hand. The findings of linguistic analyses are supported by the cultural data. The conducted research showed that there are 6 principles of nominations of fingers in the Selkup language; they are size, function, location and the absence of particular characteristics that may serve as basis for nomination. It was also found out that there are sacred principles of nomination which are connected with the personification of mythic primal forefathers of the Selkup in fingers.
\end{abstract}

Keywords: somatic vocabulary, the Selkup language, nominations of fingers, principle of nomination, finger

\section{Introduction}

Fast disappearance of languages and ancient indigenous cultures, to which the Selkup language belongs, considerably impoverishes all mankind. In this regard scientists of the whole world expand efforts on full-scale study and fixing of the languages which are under the threat of disappearance. To fulfill these tasks different research approaches are used, e.g. ethnolinguistic, cognitive, linguocultural. The present study is made within the framework of these approaches.

In spite of the fact that linguists have already conducted lots of researches in the field of lexical structure of the Selkup language (Monastyrskaya 2008; Zeremskaya 2008; Sakharova 2010; Polyakova 2012; Karmanova 2013; Persidskaya 2013), such lexical layer as somatic vocabulary, i.e. the nominations of parts of a human body, is still not studied. Nominations of parts of a body belong to the basic word stock of any language, and their study can give an idea not only about the word stock of the language but also about the worldview of the native speakers.

Vocabulary of the language that has recently acquired a written form possesses a great value as a source of historical and ethnographic data on peoples' life. The way of life of an ethnic group, its social organization and worldview are especially clearly reflected in those lexico-semantic groups of words which are regarded as being very close to terms in their character (Zvegintseva 1980). The somatic vocabulary definitely belongs to such group of words.

Linguocultural research on nominations of fingers in the Selkup language is carried out in order to identify motivation and principles of nominations of fingers; to reveal the role of these parts of a body in the Selkup culture; to restore the part of ethnos' worldview connected with fingers. Overall, the results of the study contribute to understanding of Selkups' language and mentality.

\section{Research Methods}

To achieve the goal set in the research several methods are used. The main method of analysis is component with attraction of etymological. These methods help to study derivatives of the nominations of fingers so that their inner

\footnotetext{
${ }^{1}$ This work is funded within the framework of realization of Strategic Programme on National Research Tomsk Polytechnic University Competitiveness Enhancement in the Group of Top Level World Research and Academic Institutions. 
meanings become clear which leads to understanding of the principles of nominations of different fingers in the Selkup language. Comparative method is used to show the similarity of ideas in different cultures in their attitude towards such part of a body as a finger. Linguistic data are supported by materials from the Selkup mythology and folklore in order to reveal the close interconnection between the language and the culture.

\section{Findings and Discussions}

\subsection{Etymology of the nomination mun 'finger'}

In different historical periods in the Selkup language the following nominations of a finger were recorded: O. mun, N.; mune, K., OO., NP., Tas., B., Kar.; munö, NP 'finger' (Castrén 1855); Am Tas. mun, Tomsk. munon, Narym. mun, Ket. mun, Tymische. mun 'finger' (Donner 1932); ket. mūni 'finger' (Alatalo 1998); ob., vas., tym. mun, mūn, ob. S, ket. muna, ket. mūna, tur. muni 'finger' (Bykonya 2005).

The lexemes occur in such contexts, as vas. qarindil mūn 'a curved finger'; ket. mūnam pakteptigu 'to frostbite a finger'; ob. Š tobit mūnla 'toes', odit mūnla 'fingers'; ob. Č kibaža munlat 'little fingers'. The word mun in its form coincides with protoform *munz *minz 'to curve' (Janhunen 1977). Thus, the motivation for the nomination of a finger supposed to be its physical ability to curve.

\subsection{Linguistic principles of nomination of fingers}

The nominations of certain fingers of a hand are mostly two-component words or phrases, the second component of which is the lexeme mun 'finger' in its dialectal variants. The motivations of the nominations can be divided into linguistic and cultural (sacred, mythological).

The first group is represented by the nominations based on the literal meanings of the constituent components. The motivations for the nominations of this group are:

- size: big - ket. ßeryi mūni 'thumb' (Alatalo 1998); ob. S ßaryə mun, ket. ßərga mūna 'thumb'; little - kiba mun, qibižo mūnom 'little finger (literally 'small-finger')', compare with ob., ket., vas., tym., tur. kiba 'small', ob. Č qibižo 'small';

- function: to point - ob. Š adəlžəmbəl mun 'forefinger (literally 'pointer-finger')', compare with ob. Č, tym. ādalžugu 'to point'; O. mumbelil-mun, mumbelel-mun (Castrén 1855) 'pointer finger (literally 'thimble finger')', compare with ob. Š, Č mimb'i, el. mimp'ij 'thimble'; кет. adalžigu, ob. Č adəlžəgu 'to point';

- location: middle - ob. Š sajg'i mun 'middle finger', compare with ob. Š sajgi 'middle'; last - ob. Č qal'inmun 'little finger (literally 'last finger')', compare with ket. qal'i 'last';

- absence of distinctive features that can be the basis for the nomination: nameless - O. nipketii-mun 'annulary (literally 'nameless-finger')' (Castrén 1855); ket. n'imgidi mūni 'annulary (literally 'nameless-finger')' (Alatalo 1998); ob. S nemgədi mun, ob. Š n'epkalq mun, nepkalk mun, 'annulary (literally 'nameless-finger')', compare with ob. Š, vas. nep 'name' (nip-, n'im, nem-, n'ep- are dialectal variants considering the regular alternations of vowels $i \sim e$ and consonants $m$ $\sim p$ ); elements -kalk (and its phonetic variant -kalq), -gidi (and its phonetic variants -gədi, -ketti) are the negative suffixes.

Most of the presented principles of nominations of fingers in the Selkup language coincide with the Russian principles of nominations. According to A.I. Kuznetsova, E.A. Helimsky, etc. such types of nominations are full calques from the Russian language (Zvegintseva 1980). However, this opinion can be argued as the similar principles of nominations are also presented in the northern branch of Samoyed languages and Finno-Ugric languages, compare with ngan. бәрәбта" ку 'little finger' (< ngan. бәрәбтәә 'last') (Kosterkina, et al. 2001); nen. нгумбъя 'forefinger (literally 'pointer-finger')', 'thimble', ерь нгуда тарка 'middle finger' (< ерь 'middle' + нгуда 'hand' + тарка 'finger'), нимзяда нгуда тарка 'annulary (literally 'nameless-finger')' (< ним 'name' + -зяда 'negative suffix', i.e. literally 'without namehand-finger'), варты 'little finger' (< вар 'last') (Meschaninova 1948); en. убай 'finger', 'thimble', дёдай чубай 'middle finger' (< дёдаŭ 'middle' + чубай 'finger'), барmэ 'little finger (literally 'last deer')' (Sorokina, et al. 2001); erz. v'iška sur 'little finger (literally 'small-finger')' (Kochevatkin 2001); khant. әллә пӓң 'thumb (literally 'big finger')', аләң пӓң 'forefinger (literally 'pointer-finger')', кӱmәп лой 'middle finger (literally 'middle-finger')', нэмлы луй 'annulary (literally 'without name-finger')', ай во̆щңа лӱи 'little finger (literally 'little-little finger-finger')' (Ryabchikova 2007).

\subsection{Cultural principles of nomination of fingers}

The following group of lexemes is united by mythical (sacred, cultural) motives of nominations. They are based on the names of animals and it shows the connection of human-beings with animal-totems of the tribes, their mythical potential 
and force.

Use of nominations of animals in designation of fingers of a human-being is observed in such lexemes as 0 . kanalmun 'forefinger (literally 'dog-finger')', compare with kanal 'dog'; nomal-mun 'forefinger (literally 'hare-finger')', compare with nomal 'hare'; O. kor-mun; ob. Č kor-mun, qorə mun, vas. qor mun 'middle finger (according to A. Castrén literally 'bull-finger')' (Castrén 1855).

Qanan Kanak 'dog' is a mythical ancestor Loz-seg-kanak 'black dog' which is believed to be the host of the Upper Ket (Pelikh 1998). According to mythical data, Kan was a son of Num, the God. Num threw the son on the earth and turned him into a dog, because Kan hadn't told people the secrete of immortality (Pelikh 1998). In the world view of Selkups the dog is a spirit of high rank and one of the images of mother-ancestress. Selkups regard the dog to be 'a positive character'. It is the loyal friend of its owner, after death it is buried in a grave, like a human-being (Stepanova 2008). The connection of the dog with the heavens also reveals via morphemic analysis of lexemes with meaning 'dog' (Bykonya 2011). We consider that the forefinger is designated by the name of the dog due to the supporting function of this finger when performing any work. It means that the forefinger is 'a friend' and 'an assistant' of a human-being in work, as well as the dog, that helps a Selkup in his life.

Another nomination of a forefinger nomal-mun recorded by A. Castrén has literal meaning 'hare-finger' which consists of constituent components ob. S, ket. n'o, n'ō, tym., tur. n'oma 'hare' and a suffix of an adjective -(a)l.

In the Selkup culture a hare is an animal-totem of a tribe. At the synchronous level there is a lexeme ob. S malža 'hare' for the nomination of this animal. Therefore, we can suppose that this lexeme represents the shortened form of the nomination of a tribe. Initially, the tribe was called n'omal-ža literally 'hare-father', i.e. the head of a tribe. However, in connection with a ban on speaking the god's name the change of the name of a tribe is observed. In totemic communities there was a belief that the one, who learnt a real name of somebody, would have ascendancy over its owner (Donskih 1984). It caused the appearance of a shorten name of the tribe malža in the result of loss of the first n'o component which gives the direct name of the ancestor of the tribe. The new name of the tribe can be tracked in the anthroponym Mal'kov and the name of the stamping ground Malget-Molget (Bykonya 2011).

In the somonyms with the meaning 'middle finger' the initial kor component is an independent word, compare with ob. kor 'male', 'stallion', ob., ket., tym., el. qor, ket. qorr, qorrə, tur. qori 'male force', 'male soul'. For nominations of the middle finger the literal meaning 'a finger of male force' is restored. According to culturological data, kor is a male force. It is considered that the person, who loses kor during lifetime, goes crazy, becomes a fool, mad or turns into the woman (Pelikh 1998).

Since A. Castrén gives literal meaning 'bull-finger' for the phrase qor mun (Castrén 1855), we suppose that this name of the middle finger means allegoric designation of the mythical ancestor of Piginbalk 'bull with wide open eyes'. The first component $P$ ika 'bull-warrior' is the name of the folklore character Pyka. The mythical ancestor 'bull' contains the concept 'double-hollowed' in the beliefs of the southern Selkups (Bykonya 2011), similarly to 'a double-halved tree' or a world tree in the beliefs of the northern Selkups (Prokofieva 1961). The meaning of 'double-halved' characteristic is connected with the concept of 'absence of twoness'. Fingers of a hand reveal twoness relations when considering the principle of nominations of numerals (Bykonya 1998), except the middle finger which is dual in its nature. The duality of the nature performs the function of a border between the world of people and the world of spirits.

The middle finger is an embodiment of transitional border from one world into another. It is confirmed by the fact that the middle finger halves a hand, similarly to a backbone šitikote which divides a human body into two halves: $k \beta e d i$ pil'e 'a left half' and tadi pil'e 'a right half'. According to the ethnographic data, šitikote 'middle' of a raw-hide tent is a strip which is prohibited to cross. The middle of a hand may also represent a boundary or a border which must not be crossed. The 'symbolic' border is basically the middle finger itself (Bykonya 1998).

The thumb and the little finger represent a symbolic pair. Moreover, they show the hierarchy of the mythical ancestors that have different positions from minor to major. Their polar opposition is observed: the thumb (the first, the major), 'the elder brother' and the little finger (the last, the minor), 'the younger brother'.

In the Selkup language for designation of the thumb the following group of lexemes is used: tym. qayal, qayalə; ob. Č, vas. qāyal, qayəl, vas. qaqal, qāqal; ob. Š qāgal mun; tym. kagal' mūn, qagal mun; vas. qāyal munə; ob. Č qayalt mun 'thumb', '(sacred) sepulchral soul'. The first component of the phrase kagal' mūn in its form coincides with the lexeme tym. kagal' 'sepulchral', derived from the word ob. S, Č, tym. kaga 'the dead', 'soul'. Therefore, it may be stated that the the nomination of a thumb is based on the concept according to which this finger is the place where the soul of a human-being is located. This fact is confirmed by the legend in which the person who loses the thumb turns into an animal, i.e. loses the soul. The Selkups believe that the thumb qāyal munə contains shaman's force (Pelikh 1998).

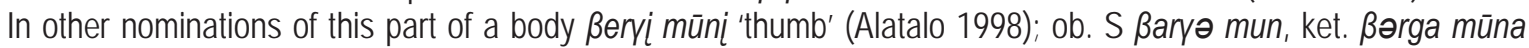
'thumb' the phonetic shape of the first component vas., tym. ßarg, tym. ßarga, ob. S ßargi, ket. ßerqi 'great', 'senior', 'big' 
underwent changes, since in the history of the language the vowel elision took place. Considering this fact, the initial form Bar-igi, Ber-iqi with the literal meaning 'the mythical ancestor-tsar' is restored (Bykonya 2011). As a result of merge of the components the leveling of their meanings occurred. In the system of kinship terms they began to designate the elder relative: ket. ßorgi, ßorq, ßəryə 'elder (brother or sister)'. The meaning 'senior in a tribe (the leader)' is found in the lexemes, in the structure of which the discussed lexical element is included: tym. Barya qup, ob. Č ßaryə qup (literally 'mythical ancestor-tsar-person'). The join with the lexeme qup 'a person' became possible after the internal meaning became minor. The same meaning is found in the lexeme ob. Č ßaryol 'tsar', 'governor', 'shaman', 'owner' (< Bar-oy-ol literally 'mythical ancestor-tsar-head (leader)' (Bykonya 2011).

The presence of connection with shaman force, i.e. the strongest force among people, and the meaning 'senior in a tribe (leader)' in the considered variants of nominations of a thumb gives the reasons to claim that a thumb is an embodiment of the mythical primal forefather of the highest rank.

As opposed to culturological meaning of the thumb, it is worth considering the meaning of the little finger in the spiritual culture of the Selkups. The first component of the nomination ob. Ć qal'inmun 'little finger (literally 'the last finger')' derives from the personal name of the ancestor-warrior from the river Ket Kalguk - Qalguk (Kalguk) (Chesnov 1971). According to the legend, Kalguk 'a spirit-warrior', 'a stone person' shot an arrow into thunder, turned into a stone idol, and went into the ground (Pelikh 1972). He was a laborer of 'the big warrior' who ordered him to shoot an arrow into thunder, but the big warrior himself turned into a stone in the ground. The morphemic decomposition of the lexeme allows differentiating components qal-guk. The first component qal- is differentiated in the structure of the names of totems: birdtotem - ob. S kalak 'seagull' and mammal-totem, worshipped in the image of mole cricket ket. kalli, qal'el'i, qall'i, qall'in; vas. qalat 'mole' (Bykonya 2011).

The lexemes in the structure of which component kal- qal- is differentiated refer to designation of elements of the sacred sphere: ob. Š kal'ittab 'armpit'; ob. Č, ket. qal'i; ket. qāll 'bosom' (regarded to be a representation of Underworld); qalto 'the watershed lake (two rivers flow from it in different directions)' (Bykonya 2011). The little finger belongs to the sacred sphere as well - ob. Č qal'in mun 'a little finger of a hand'.

Another nomination of the little finger tym. čel'ka may be considered as a secret name of a child. In the self-name of the Selkups ču-gula component $\check{c} u$ - can be differentiated. The form of this component coincides with the lexeme ob. Č $\check{c} u$; tym. čü; ob. Š, Č, ket., vas., tym. č'u 'earth', 'clay', 'country'. This associative connection gives the grounds to treat the ethnonym čugula as 'earth people'. The name of the mythical ancestor 'earth' is transferred to the place of a tribe origin/birth of a baby. The semantic content of cognate words leads to the conclusion that the lexemes če, ču and č'u were secret (domestic) names of children of different age. The lexeme če is included into structure of a compound word qibajče 'a child'. Connection of the mythical ancestor with a child can be found at other levels. The symbol of this connection is represented by tym., ob. Č č'oye 'a belt (of the mythical ancestor that connects him with the souls of the born children)', e.g. ob. Č mat qibajčem qomdel č'oye ek 'my child with a gold belt, literally 'my-child-gold-belt-is' (Bykonya 2011).

According to mythological data, about subordinate position of the ancestor-warrior Kalguk and the use of the nomination of the little finger to name children who have similar subordinate position towards adult, we can claim that the little finger represents the mythical ancestor, who is at lower hierarchical level in comparison with the ancestors-totems represented in a thumb.

The embodiment of 'subordinate' position in a little finger is traced in the Russian language as well. In Russian the nomination of a little finger comes from the Common Slavic form мгзииньць from which the following words were derived: rus. and ch.-slav. мгззиньць 'the younger son', old rus. мизиньць, ukr. мизи́нець 'the younger child' and мизинка 'the younger daughter'. The word мизинец 'little finger' had the meaning 'small', 'the smallest', 'smaller': мизинный сын 'the youngest son', мизинии люди 'people of a low rank', мизиниться пред кем-либо 'to let smth. pass', 'to demean oneself' (Ovchukhova 2013).

The fact, that there is no special nomination for the ring finger, can be connected with absence of a certain function of this finger, or it has special sacred meaning about which it is forbidden to speak.

\section{Concluding Remarks}

The analysis of etymological data showed that the general nomination of a finger mun in the Selkup language comes from the Proto-Samoyed verb *munz 'to curve'. This initial meaning of the lexeme is likely to be the principle of nomination of a finger based on the physical ability of this part of a body to curve.

Linguistic approach in analysis of the nominations of fingers in the Selkup language allowed allocation of 6 motivations for their nominations, they are: size, function, location and absence of distinctive features forming a basis for 
designation of a finger. These principles are not exclusive and can be found in other Samoyed and Finno-Ugric languages.

While carrying out the linguocultural analysis, the sacred principles of nomination, which are based on the embodiment of mythical primal forefathers in fingers, were brought to light. Thus, a thumb is an embodiment of the mythical primal forefather of the highest rank (ßervi mūni) and the place where the soul of a human-being is located (qayalt mun). The nominations of a forefinger represent a spirit of high rank (kanal-mun literally 'dog-finger') and an animal-totem of a tribe (nomal-mun literally 'hare-finger'). Somonym qor mun 'middle finger (literally 'bull-finger')' is a symbol of a male force. Lexemes qal'inmun and c'el'ka 'little finger' represent the mythical ancestor of a lower hierarchical level.

The bases for the nominations of parts of a human body are the features of the culture and contain valuable information about hierarchy of mythical ancestors in the pantheon according to the Selkups' beliefs.

\section{References}

Monastyrskaya, E. A. (2008) Lexico-semantic field of mentality and negative emotions of anger, fear and sorrow in the Selkup language. Thesis candidate of philology. Joshkar-Ola.

Zeremskaya, Yu. A. (2008) Kinship terms in the Selkup language. Thesis candidate of philology. Joshkar-Ola.

Sakharova, O. V. (2010) Floral vocabulary in the Selkup language. Thesis candidate of philology. Joshkar-Ola.

Polyakova, N.V. (2012) "Sacred places" in the worldview of the Selkups. Tomsk State Pedagogical University Bulletin, 10 (125), $85-88$.

Karmanova, Yu. A. (2013) Lexical layer of zoonyms in the Selkup language. Thesis candidate of philology. Saransk.

Persidskaya, A. S. (2013) Nominations of a heart in Selkup dialects (comparative analysis). Tomsk State Pedagogical University Bulletin, 30 (131), $72-76$.

Zvegintseva, V. I. (1980) Essays on the Selkup language. Tas dialect. Volume I.

Castrén, M. A. (1855) Dictionary of Samoyed languages. Saint Petersburg.

Donner, K. (1932) Dictionary of Samoyed languages. Helsinki.

Alatalo, Ya. (1998) Selkup-Russian and Russian-Selkup Dictionary. Helsinki

Bykonya, V. V. (2005) Selkup-Russian Dialectal Dictionary. Tomsk. TSPU Publishing house.

Janhunen, J. (1977) Dictionary of Samoyed languages (Etymology of Samoyed languages). Helsinki.

Kosterkina, N. T., Momde, A. Ch., Zhdanova, T. Yu. (2001) Nganasan-Russian and Russian-Nganasan Dictionary. Saint-Petersburg. Prosveschenie Publishing.

Meschaninov, I. I. (1948) Russian-Nenets Dictionary. Moscow.

Sorokina, I. P., Bolina, D. S. (2001) Enets-Russian and Russian-Enets Dictionary. Saint-Petersburg. Prosveschenie Publishing.

Kochevatkin, A. M. (2001) Somatic vocabulary in the dialects of Erzya (linguiogeographical analysis). Saransk. Krasnyj Oktyabr Publishing.

Ryabchikova, Z. S. (2007) Somatic vocabulary of Khanty. Thesis candidate of philology. Saint-Petersburg.

Pelikh, G. I. (1998) Selkup mythology. Tomsk. NTL Publishing.

Stepanova, O. B. (2208) Traditional worldview of the Selkup. Thesis candidate of philology. Saint Petersburg.

Bykonya, V. V. (2011) Selkups: language and culture (ethnolinguistic outline). Tomsk. TSPU Publishing house.

Donskih, O. A. (1984) The origin of a language as an issue of philosophy. Novosibirsk.

Prokofieva, E. D. (1961) Worldview of the Selkup shamans. SAME. Volume XX. Leningrad.

Bykonya, V. V. (1998) Numerals in the Selkup worldview. Tomsk. TSPU Publishing house.

Chesnov, Ya. V. (1971) The early forms of ethnonyms and ethnic self-awareness. Ethnography on names. Moscow, 6-13.

Pelikh, G. I. (1972) The origin of the Selkups. Tomsk. TSU Publishing house.

Ovchukhova, Yu. O. (2013) Fingers of a hand in the linguistic worldview. Medical Bulletin of Internet-Conferences. Volume 3. [Online] Available: http://cyberleninka.ru/article/n/paltsy-ruk-v-russkoy-yazykovoy-kartine-mira (March 2, 2015). 